\title{
FACTORS AFFECTING THE ACCEPTANCE OF MOBILE PAYMENT SYSTEMS IN JORDAN: THE MODERATING ROLE OF TRUST
}

\author{
Manaf Al-Okaily ${ }^{1}$ \\ School of Business, Jadara University (JU), Jordan. \\ *Corresponding author (Email: m.alokaily@jadara.edu.jo) \\ Mohd Shaari Abd Rahman ${ }^{2}$ \\ Faculty of Business, Economics \& Social Development, Universiti Malaysia Terengganu (UMT), Malaysia. \\ (Email: shaari@umt.edu.my)

\section{Azwadi Ali ${ }^{3}$} \\ Faculty of Business, Economics \& Social Development, Universiti Malaysia Terengganu (UMT), Malaysia.
} (Email: azwadi@umt.edu.my)

Received date: 01-10-2019

Revised date: $20-10-2019$

Accepted date: 04-11-2019

Published date: 10-12-2019

To cite this document: Al-Okaily, M., Abd Rahman, M. S., \& Ali, A. (2019). Factors Affecting the Acceptance of Mobile Payment Systems in Jordan: The Moderating Role of Trust. Journal of Information System and Technology Management, 4(15), 16-26.

DOI: $10.35631 /$ jistm.415002

Abstract: Nowadays, the smartphone applications play a critical role in every aspect of our life, as in the case of Jordan Mobile Payment (JoMoPay) system that can be used to save time, effort and money. Despite the immense benefits of JoMoPay system services, their acceptance by users in Jordan is very low. Moreover, the related issues of JoMoPay system has not been addressed substantially in the Jordanian context. In this respect, the research model proposed in this paper seeks to synthesize the extended Unified Theory of Acceptance and Use of Technology (UTAUT2) model variables namely; Performance Expectancy (PE), Effort Expectancy (EE), Social Influence (SI), Peer Influence (PI), Facilitating Conditions (FC), Hedonic Motivation (HM), Price Value (PV) and Habit (HT) as immediate predictors of intentions of users to accept JoMoPay system. In addition, to join new variables namely; Trust (TR) as the moderating effect among them.

Keywords: M-Payment, JoMoPay System, UTAUT2, Acceptance, Trust and Jordan

\section{Introduction}

Lately, the use of mobile devices has surged worldwide (Vallespín, Molinillo \& Ramos, 2018). The newest statistics showed that the total number of mobile phone users worldwide is more than 4.3 billion people in 2017 (International Telecommunication Union [ITU], 2017; Statista, 2017). However, the number of mobile phone users around the world is expected to reach 5 billion by 2019 (Statista, 2019). More specifically, Jordan and other countries of the Middle 
East recorded a very high penetration when it comes to mobile phones which is a great opportunity for improving and promoting financial and economic inclusion (Central Bank of Jordan [CBJ], 2017; Sehwail \& Bahou, 2017; Ghazal, 2015). Recent statistics showed that the number of active mobile phones in Jordan reached 16,746,000 in 2016 at a penetration rate of $168 \%$ of the Jordanian population (Ghazal, 2017a; Ghazal, 2017b; Ministry of Information and Communications Technology [MOICT], 2017a; MOICT, 2017b; Telecommunications Regulatory Com-mission [TRC], 2016). Based on developments mentioned above, several developed and developing countries have commenced to providing mobile payment systems services which allows companies and individuals to interact with one another by using payment transactions and utilizes applications of mobile phones.

Therefore, the rates of internet and mobile phones penetration form a great foundation to use mobile payment system. However, the level of acceptance of mobile payment system in Jordan is still below expectation (Alalwan, Baabdullah, Rana, Tamilmani \& Dwivedi, 2018; Gharaibeh \& Arshad, 2018; Alalwan, Dwivedi \& Rana, 2017; Qasim \& Abu-Shanab, 2016; Alalwan, Dwivedi \& Williams, 2016; Qatawneh, Aldhmour \& Alfugara, 2015; Jaradat \& Al-Mashaqba, 2014; Jaradat \& Faqih, 2014). Although experiences from other nations showed that meagre payments are more popular on mobile phones which has not been popular in Jordan until recent years (Qasim \& Abu-Shanab. 2016). One example, mobile payments in China improved by up to $255 \%$ in the first three months of 2014, and the mobile payment market accounted for US\$623 billion in the year of 2014 (Marketingtochina [MC], 2015). In contrast, the number of transactions executed through the Jordan mobile payment (JoMoPay) system in the year of 2015 do not exceed $1 \%$ and only reached 835 transactions totalling about US $\$ 35,601$ (A1 Shawwa, 2016; CBJ, 2015). Thus, the JoMoPay system is still limited in the Jordanian environment and its rate of adoption has been found in very low percentages.

Based on the discussion above, the main objective of this paper was to understand users' intentions in Jordan to accept JoMoPay system by investigation to determine the main predictors by using UTAUT2 model. The stem significance of this study is to investigate mobile payment system acceptance in the Jordanian context which has not been addressed substantially in the Arab world contexts. Another reason for the significance of such studies comes with the deep expansion of smartphones usage around the globe. These days, the use of mobile phones and their applications play an important role in every aspect of our life. In real areas, smartphones have made some important changes regarding payment transactions operations in the last recent years, which led to the improvements of digital payment transactions though using the mobile payment systems that can be used to save time, effort, and money. Due to the popularity of mobile phones and the Internet, the use of mobile payment system is becoming an appealing option that has recently boomed because of the advent of smartphones and their applications across the world.

This paper introduces the concept of a mobile payment system which can be organized as follows: the first section is the introduction of the research, followed by the background of UTAUT model, the research model, research hypotheses and the operational definitions utilized in the research model. Finally, the structure of the whole paper is highlighted by the conclusion.

\section{Background of UTAUT Model}

Unified Theory of Acceptance and Use of Technology (UTAUT2) model was originally proposed by Venkatesh, Thong and Xu (2012) and was applied as a conceptual model in this paper to clarify the JoMoPay system acceptance from users' perspective of Jordanian context. 
UTAUT model has been formulated based on the combination of eight major theories and models of technology acceptance (Venkatesh, Morris, Davis \& Davis, 2003). The models that were integrated to formulate the UTAUT were: Theory of Reasoned Action (TRA), Theory of Planned Behavior (TPB), Social Cognitive Theory (SCT), Technology Acceptance Model (TAM), Innovation Diffusion Theory (IDT), Model of PC Utilization (MPCU), Motivational Model (MM), Combined TAM and TPB (C-TAM-TPB). However, UTAUT integrates the technology acceptance domain into one theory with behavioral intention and user behavior as the main dependent variables. This model tries to overcome the difficulties faced by information technology researchers to develop their studies' framework to understand users' acceptance of the technology (Venkatesh et al., 2012; Venkatesh et al., 2003). Figure 1 show all of those models and theories were integrated into UTUAUT model.

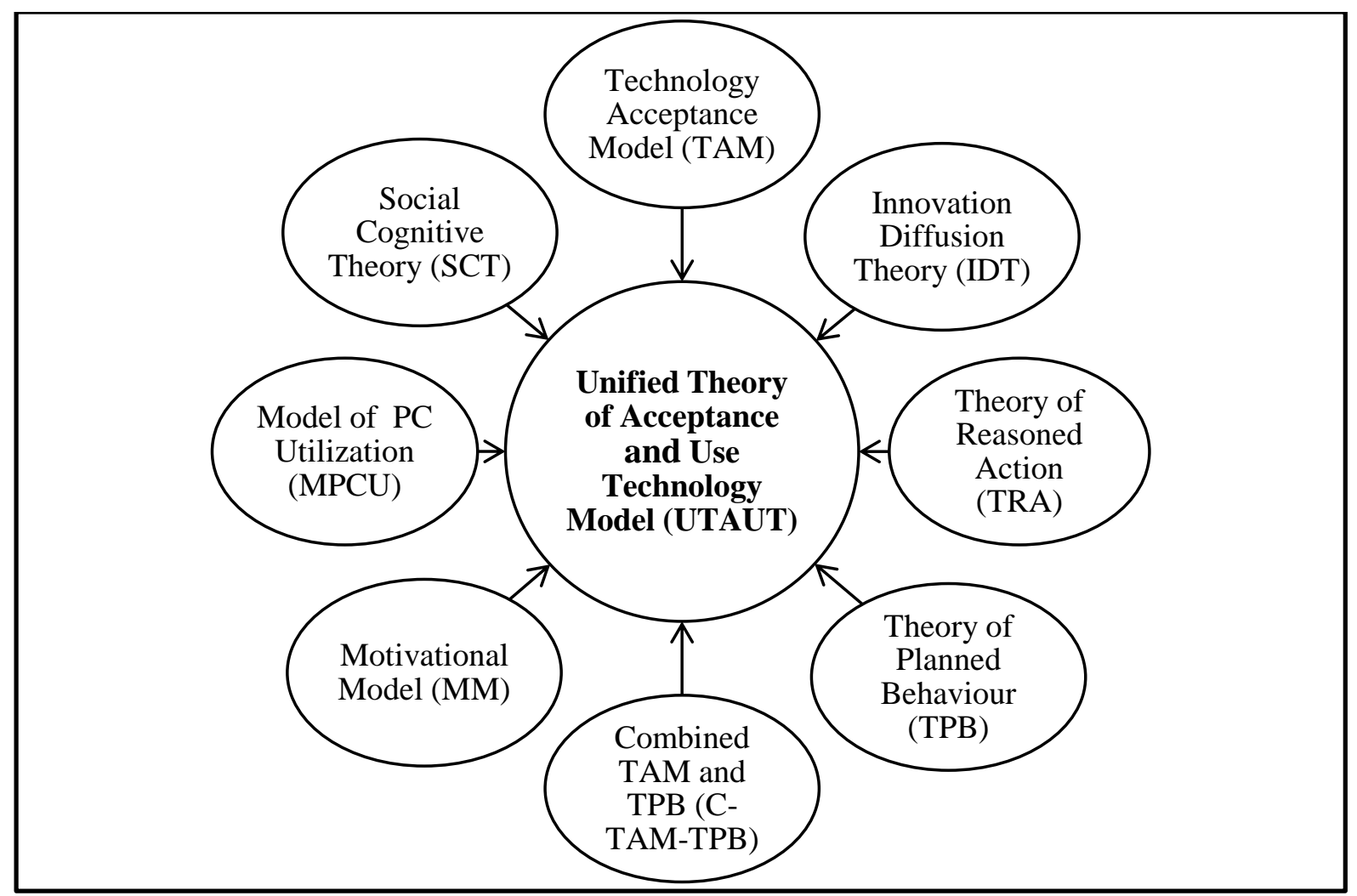

Figure 1: Integration of Eight Theories and Models to Access UTAUT Model.

UTAUT model has four main factors which influence behavioral intention to use a technology and usage behaviours namely performance expectancy, effort expectancy, social influence, and facilitating conditions. The relationships between these factors, behaviour intention and behaviour to use are moderated by four key factors including gender, age, experience and voluntariness of use (Venkatesh et al., 2003). Figure 2 display the components of the UTAUT model. 


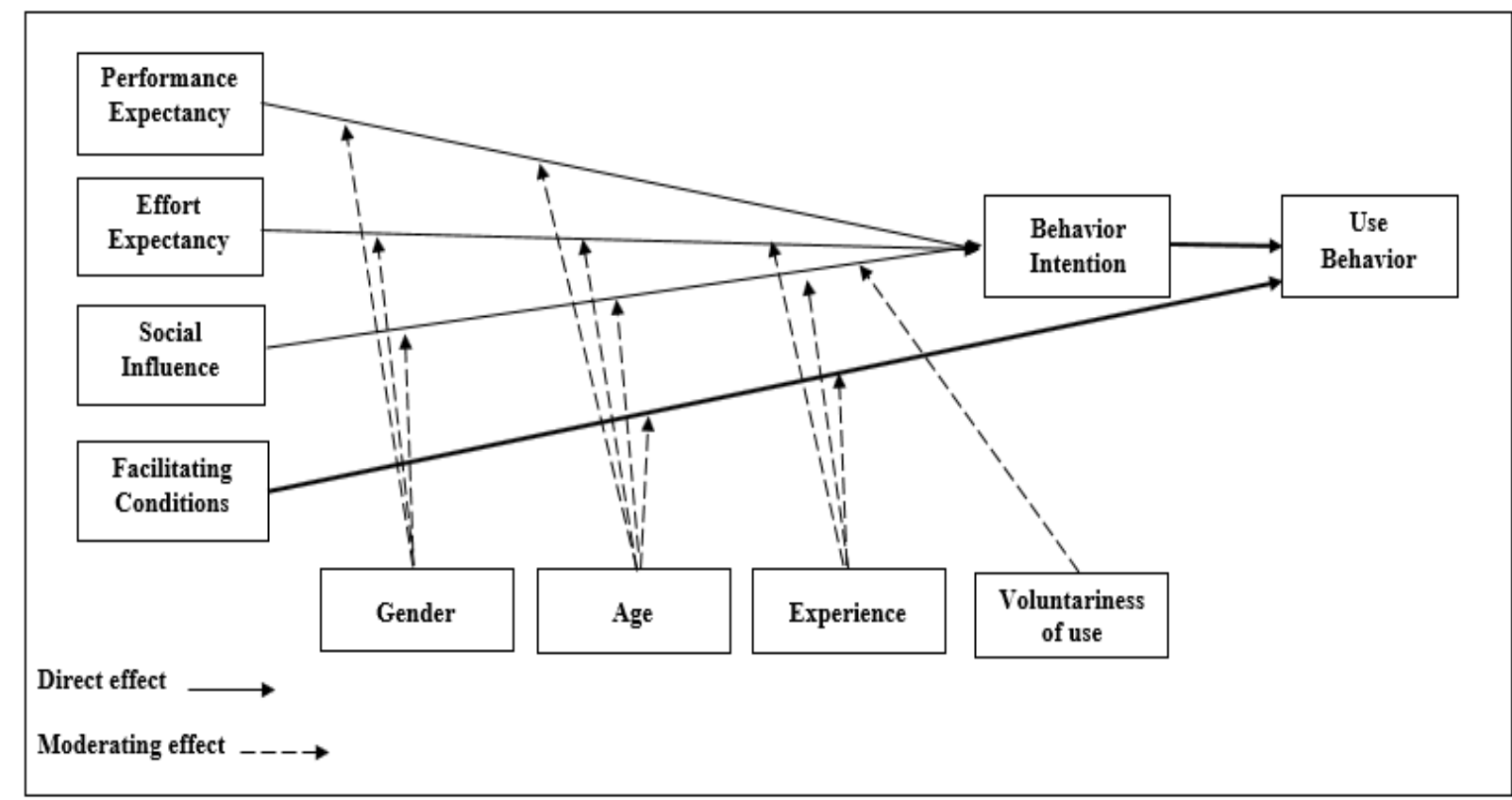

Figure 2: Unified Theory of Acceptance and Use of Technology (UTAUT) Model

Source: Venkatesh et al. (2003)

At a later stage, Venkatesh et al. (2012) developed and made some modifications to the UTAUT model based on their findings from a research conducted in Hong Kong. Three new factors were added to the original UTAUT model. The first factor is hedonic motivation, the second factor is price value, and habit is the third one forming the new UTAUT2 model. Moreover, Venkatesh et al. (2012) claim that the suggested additions in UTAUT2 exhibited significant changes in the variance explained in behavioral intention and technology use. In total, the new UTAUT2 model posits seven factors as the determinants of behavioral intention and use of technology.

The factors include performance expectancy, effort expectancy, social influence, facilitating conditions, hedonic motivation, price value and habit. They are moderated through irregular degree by gender, age, and experience as shown in Figure 3. In view of this, since UTAUT2 model is relatively new, recommended to more development and validation of the model were suggested in different contexts such as new context, new culture and new technology as in the case in this paper. 


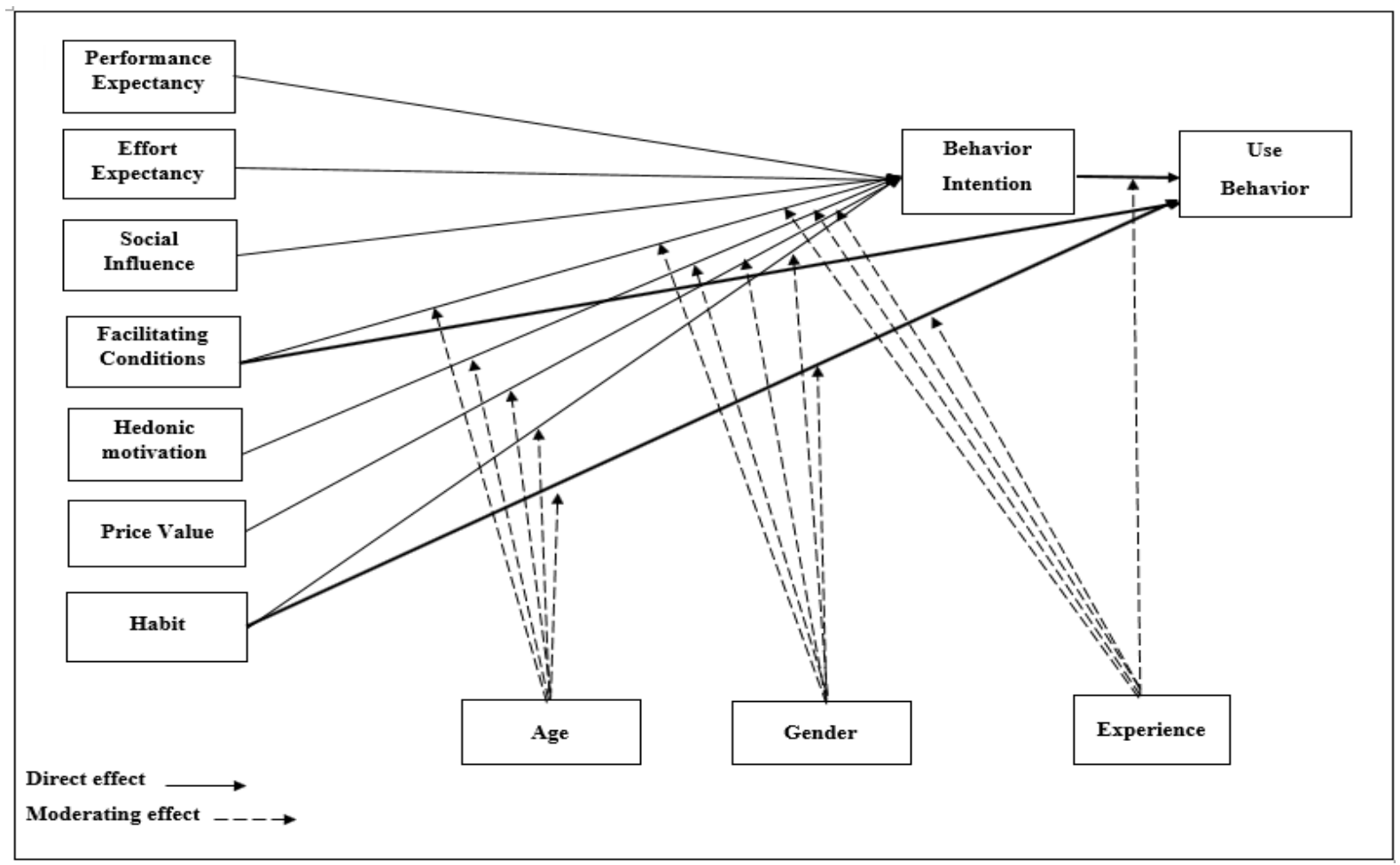

Figure 3: Unified Theory of Acceptance and Use of Technology (UTAUT2) Model Source: Venkatesh et al. (2012)

However, in the pursuit of choosing appropriate model covering almost all factors predicting users' intentions to accept JoMoPay system, the UTAUT2 model has been identified as a fit theoretical basis for the theoretical model utilized in the present paper. As drawn in Figure 4, the key factors of UTAUT2 model are performance expectancy, effort expectancy, social influence, facilitating conditions, hedonic motivation, price value and habit which were proposed as immediate predictors of the intention of users to use JoMoPay system. Further, peer influence and trust were integrated into UTAUT2 model as external factors in the same theoretical model, which is endorsed by Venkatesh et al. (2012) to widen the theoretical prospect of UTAUT2 model.

In this paper, it should also be noted that this paper considers neither the role of user behavior nor the moderating effect of gender, age, experience, and voluntariness of use in the conceptual model. Since the JoMoPay system is a new payment method in Jordan, it has a very low adoption rate (Alalwan et al., 2017; Qasim \& Abu-Shanab, 2016; Jaradat \& Al-Mashaqba, 2014; Jaradat \& Faqih, 2014). Thus, the current paper will focus on investigating intention to use JoMoPay system for non-users rather than actual users. Hence, user's behaviour (for actual users) was excluded in this paper. Lastly, with regard to the moderating effect of gender, age, experience, and voluntariness of use, there are many studies that have excluded user's behavior and moderating role in their studies (e.g., Alalwan et al. 2017; El-Masri \& Tarhini, 2017; Qasim \& Abu-Shanab, 2016; Afshan \& Sharif, 2016; Morosan \& DeFranco, 2016; De-Sena Abrahão, Moriguchi, \& Andrade, 2016; Slade, Dwivedi, Piercy \& Williams, 2015; Alshare \& Mousa, 2014; Raman \& Don; 2013), which has commonly been the case amongst adoption studies that employ UTAUT model (Venkatesh et al., 2012). 


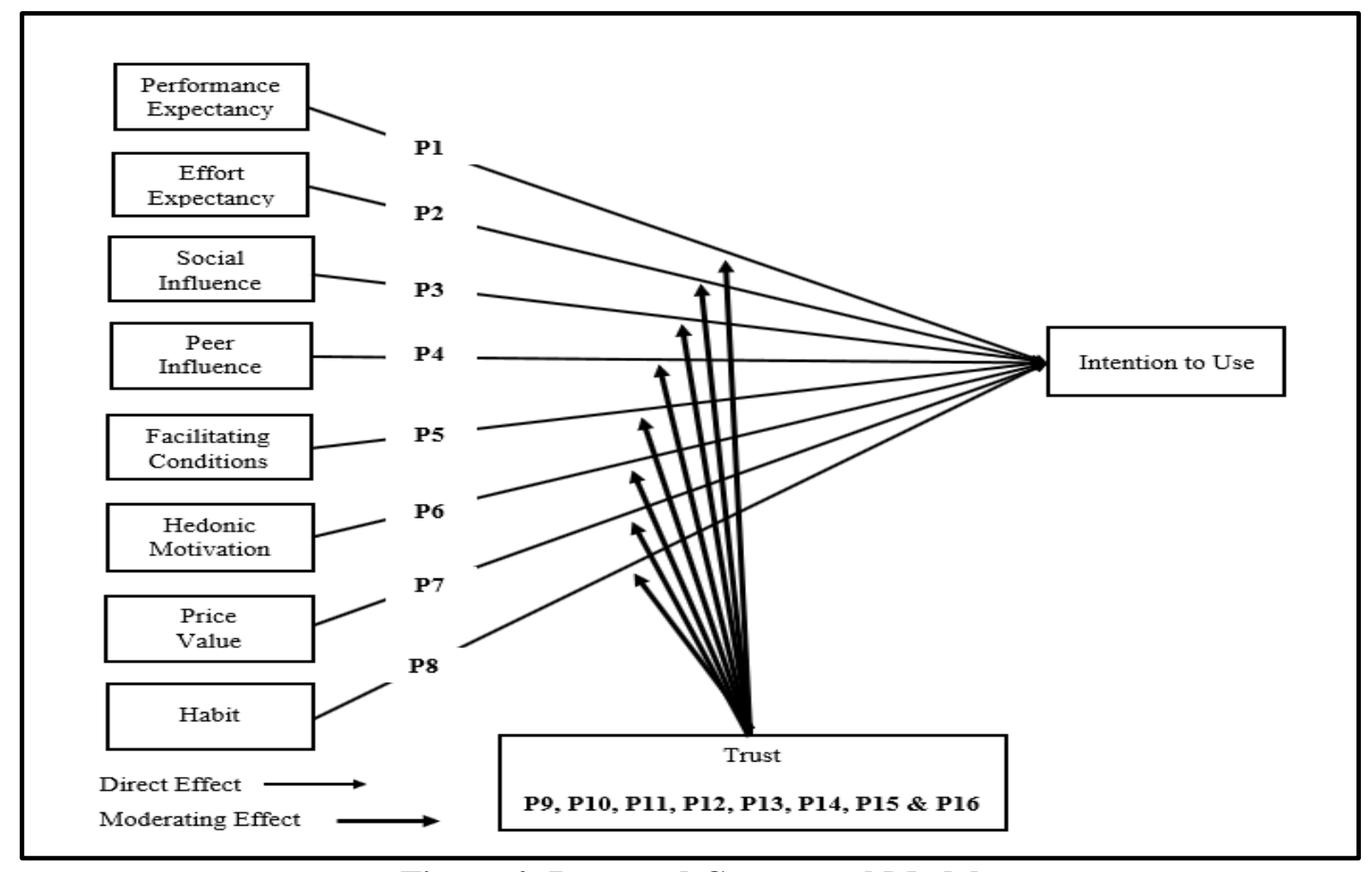

Figure 4: Proposed Conceptual Model

As stated in figure 4, the current paper discusses the direct relationships between (1) performance expectancy as the independent variable and intention to use JoMoPay system as the dependent variable, (2) effort expectancy as the independent variable and intention to use JoMoPay system as the dependent variable, (3) social influence as the independent variable and intention to use JoMoPay system as the dependent variable, (4) peer influence as the independent variable and intention to use JoMoPay system as the dependent variable, (5) facilitating conditions as the independent variable and intention to use JoMoPay system as the dependent, (6) hedonic motivation as the independent variable and intention to use JoMoPay system as the dependent variable, (7) price value as the independent variable and intention to use JoMoPay system as the dependent variable, and (8) habit as the independent variable and intention to use JoMoPay system as the dependent variable.

Then, there is a discussion on the indirect relationship between (9) trust acts as the moderating variable between performance expectancy as the independent variable and intention to use JoMoPay system as the dependent variable, (10) trust acts as the moderating variable between effort expectancy as the independent variable and intention to use JoMoPay system as the dependent variable, (11) trust acts as the moderating variable between social influence as the independent variable and intention to use JoMoPay system as the dependent variable, (12) trust acts as the moderating variable between peer influence as the independent variable and intention to use JoMoPay system as the dependent variable, (13) trust acts as the moderating variable between facilitating conditions as the independent variable and intention to use JoMoPay system as the dependent variable, (14) trust acts as the moderating variable between hedonic motivation as the independent variable and intention to use JoMoPay system as the dependent variable, (15) trust acts as the moderating variable between price value as the independent variable and intention to use JoMoPay system as the dependent variable, and (16) trust acts as the moderating variable between habit as the independent variable and intention to use JoMoPay system as the dependent variable. Thus, there are sixteen hypotheses formulated 
to exam the different relationships in proposed research model. Lastly, Table 1 presented the summary of the direct and indirect proposed hypotheses.

Table 1: Summary of Direct and Indirect Proposed Hypotheses

\begin{tabular}{|c|c|c|c|c|}
\hline No. & Hypotheses Development for Independent Variables & \multicolumn{2}{|l|}{ IV } & DV \\
\hline $\mathbf{P 1}$ & $\begin{array}{l}\text { Intention to use JoMoPay system will be positively influenced } \\
\text { by performance expectancy. }\end{array}$ & \multicolumn{2}{|l|}{$\mathrm{PE}$} & IU \\
\hline $\mathbf{P 2}$ & $\begin{array}{l}\text { Intention to use JoMoPay system will be positively influenced } \\
\text { by effort expectancy. }\end{array}$ & \multicolumn{2}{|c|}{$\mathrm{EE}$} & IU \\
\hline P3 & $\begin{array}{l}\text { Intention to use JoMoPay system will be positively influenced } \\
\text { by social influence. }\end{array}$ & \multicolumn{2}{|l|}{ SI } & IU \\
\hline $\mathbf{P 4}$ & $\begin{array}{l}\text { Intention to use JoMoPay system will be positively influenced } \\
\text { by peer influence. }\end{array}$ & \multicolumn{2}{|l|}{ PI } & IU \\
\hline P5 & $\begin{array}{l}\text { Intention to use JoMoPay system will be positively influenced } \\
\text { by facilitating conditions. }\end{array}$ & \multicolumn{2}{|c|}{$\mathrm{FC}$} & IU \\
\hline P6 & $\begin{array}{l}\text { Intention to use JoMoPay system will be positively influenced } \\
\text { by hedonic motivation. }\end{array}$ & \multicolumn{2}{|c|}{$\mathrm{HM}$} & IU \\
\hline P7 & $\begin{array}{l}\text { Intention to use JoMoPay system will be positively influenced } \\
\text { by price value. }\end{array}$ & \multicolumn{2}{|c|}{ PV } & IU \\
\hline P8 & $\begin{array}{l}\text { Intention to use JoMoPay system will be positively influenced } \\
\text { by habit. }\end{array}$ & \multicolumn{2}{|c|}{ HA } & IU \\
\hline No. & Hypotheses Development for Moderates Variables & IV & MOD & DV \\
\hline P9 & $\begin{array}{l}\text { Trust moderate the relationship between performance } \\
\text { expectancy and intention to use JoMoPay system. }\end{array}$ & $\mathrm{PE}$ & TR & IU \\
\hline P10 & $\begin{array}{l}\text { Trust moderate the relationship between effort expectancy and } \\
\text { intention to use JoMoPay system. }\end{array}$ & $\mathrm{EE}$ & $\mathrm{TR}$ & IU \\
\hline P11 & $\begin{array}{l}\text { Trust moderate the relationship between social influence and } \\
\text { intention to use JoMoPay system. }\end{array}$ & SI & $\mathrm{TR}$ & IU \\
\hline P12 & $\begin{array}{l}\text { Trust moderate the relationship between peer influence and } \\
\text { intention to use JoMoPay system. }\end{array}$ & PI & $\mathrm{TR}$ & IU \\
\hline P13 & $\begin{array}{l}\text { Trust moderate the relationship between facilitating conditions } \\
\text { and intention to use JoMoPay system. }\end{array}$ & $\mathrm{FC}$ & $\mathrm{TR}$ & IU \\
\hline P14 & $\begin{array}{l}\text { Trust moderate the relationship between hedonic motivation } \\
\text { and intention to use JoMoPay system. }\end{array}$ & HM & $\mathrm{TR}$ & IU \\
\hline P15 & $\begin{array}{l}\text { Trust moderate the relationship between price value and } \\
\text { intention to use JoMoPay system. }\end{array}$ & PV & $\mathrm{TR}$ & IU \\
\hline P16 & $\begin{array}{l}\text { Trust moderate the relationship between habit and intention to } \\
\text { use JoMoPay system. }\end{array}$ & HA & $\mathrm{TR}$ & IU \\
\hline
\end{tabular}

In short, the predominant research thread of this topic is investigating factors that either act as incentives or act as barriers to the acceptance of mobile payment systems. In this regard, recent literature of m-payment indicated that there are several important factors that affect the users' intentions including peer influence and trust which have not been covered by the UTAUT2 model. Consequently, the new model still needs to be developed for a deeper understanding of the phenomenon of JoMoPay system acceptance. Therefore, this paper proposed an interactive view of JoMoPay system acceptance by explicitly considering peer influence as an independent variable and trust as a moderating variable in the UTAUT2 model. In this paper, UTAUT2 model was being extended to cover all critical factors in order to build the proposed research 
model. Lastly, Table 2 below present the summary of operational definitions utilized in the research proposed framework.

Table 2: Summary of Operational Definitions Utilized in the Proposed Model

\begin{tabular}{|c|c|c|}
\hline Constructs & Operational Definition & Sources \\
\hline $\begin{array}{l}\text { Performan } \\
\text { ce } \\
\text { Expectancy }\end{array}$ & $\begin{array}{l}\text { "The degree to which an individual believes that using the } \\
\text { system will help him or her to attain gains in job } \\
\text { performance", }\end{array}$ & $\begin{array}{l}\text { Venkatesh et } \\
\text { al. }(2003, \mathrm{p} \text {. } \\
\quad 447)\end{array}$ \\
\hline $\begin{array}{l}\text { Effort } \\
\text { Expectancy }\end{array}$ & "The degree of ease associated with the use of the system" & $\begin{array}{l}\text { Venkatesh et } \\
\text { al. }(2003, \mathrm{p} \text {. } \\
\quad 450)\end{array}$ \\
\hline $\begin{array}{l}\text { Social } \\
\text { Influence }\end{array}$ & $\begin{array}{l}\text { "The degree to which an individual perceives the } \\
\text { importance of others to believe that he or she should use the } \\
\text { new system", }\end{array}$ & $\begin{array}{l}\text { Venkatesh et } \\
\text { al. (2003, p. } \\
\quad 451)\end{array}$ \\
\hline $\begin{array}{l}\text { Peer } \\
\text { Influence }\end{array}$ & $\begin{array}{l}\text { The degree to which individuals adjust their opinions and } \\
\text { attitudes based on the opinions and attitudes of their close } \\
\text { associates. }\end{array}$ & Moody (2001) \\
\hline $\begin{array}{l}\text { Facilitating } \\
\text { Condition }\end{array}$ & $\begin{array}{l}\text { "The degree to which an individual believes that an } \\
\text { organizational and technical infrastructure exists to support } \\
\text { the use of the system" }\end{array}$ & $\begin{array}{l}\text { Venkatesh et } \\
\text { al. }(2003, \mathrm{p} \text {. } \\
\quad 453)\end{array}$ \\
\hline $\begin{array}{l}\text { Hedonic } \\
\text { motivation }\end{array}$ & The fun or pleasure derived from using a technology. & $\begin{array}{l}\text { Venkatesh et } \\
\text { al. (2012) }\end{array}$ \\
\hline Price Value & $\begin{array}{l}\text { The individuals' cognitive trade-off between the perceived } \\
\text { benefits of the applications and the monetary cost for using } \\
\text { them. }\end{array}$ & $\begin{array}{c}\text { Venkatesh et } \\
\text { al. (2012) }\end{array}$ \\
\hline Habit & $\begin{array}{l}\text { The extent to which people tend to perform behaviors } \\
\text { automatically because of learning accumulated from their } \\
\text { experience in using certain technology. }\end{array}$ & $\begin{array}{c}\text { Venkatesh et } \\
\text { al. (2012) }\end{array}$ \\
\hline Trust & $\begin{array}{l}\text { The defined as customer trust in Mobile banking can be } \\
\text { operationalized as the accumulation of customer beliefs of } \\
\text { integrity, benevolence, and ability that could enhance } \\
\text { customer willingness to depend on Mobile banking to attain } \\
\text { the financial transactions. }\end{array}$ & $\begin{array}{l}\text { Gefen et al. } \\
(2003)\end{array}$ \\
\hline $\begin{array}{l}\text { Intention to } \\
\text { Use }\end{array}$ & $\begin{array}{l}\text { "A measure of the strength of one's intention to perform a } \\
\text { specified behavior" }\end{array}$ & $\begin{array}{l}\text { Davis et al. } \\
(1989, \text { p. } 984)\end{array}$ \\
\hline
\end{tabular}

\section{Conclusion}

It is worth mentioning that the UTAUT2 model confirms how can different critical factors motivate the acceptance of new technology. Besides, previous studies emphasized other factors related to technology acceptance as motivational factors. Interestingly, this paper tries to offer critical success factors that can lead to increase the rate of acceptance of JoMoPay system in the Jordanian context. Consequently, the proposed model in this paper was based on the UTAUT2 model which covers most of the independent variables including performance expectancy, effort expectancy, social influence, facilitating conditions, hedonic motivation, price value and habit. Further, this paper has also expanded the UTAUT2 model to cover two new factors namely; peer influence and trust to test the acceptance of JoMoPay system among Jordanian users. Thus, sixteen hypotheses were formulated and will be examined in the future research through actual data. 


\section{References}

Afshan, S., \& Sharif, A. (2016). Acceptance of mobile banking framework in Pakistan. Telematics and Informatics, 33(2), 370-387.

Al Shawwa M. (2016, May 7). The $2^{\text {nd }}$ Electronic and Mobile payments in the Arab world conference - Presentation on the Jordan Retail Banking Survey and findings of the E \& $M$ Banking services [Video file]. Retrieved from https://www.youtube.com/watch?v=WLeikg3AFA4.

Alalwan, A. A., Baabdullah, A. M., Rana, N. P., Tamilmani, K., \& Dwivedi, Y. K. (2018). Examining adoption of mobile internet in Saudi Arabia: Extending TAM with perceived enjoyment, innovativeness and trust. Technology in Society, 55, 100-110.

Alalwan, A. A., Dwivedi, Y. K., \& Rana, N. P. (2017). Factors influencing adoption of mobile banking by Jordanian bank customers: Extending UTAUT2 with trust. International Journal of Information Management, 37(3), 99-110.

Alalwan, A. A., Dwivedi, Y. K., \& Williams, M. D. (2016). Customers' intention and adoption of telebanking in Jordan. Information Systems Management, 33(2), 154-178.

Al-Okaily, M. M., \& Rahman, M. S. A. The Impact of Implementing Web-Trust Principles on the Quality of Accounting Information Issued by Jordanian Banks. Journal of Business and Management 19 (7), 61-70.

Al-Okaily, M. M., \& Rahman, M. S. A. The Impact of Implementing Web Trust Principles on the Efficiency of Accounting Information System in Commercial Banks at Jordan. Journal of Business and Management 19 (7), 71-80.

Alshare, K., \& Mousa, A. (2014). The moderating effect of espoused cultural dimensions on consumer's intention to use mobile payment devices. Proceedings of Thirty-Fifth International Conference on Information Systems. Auckland, New Zealand.

Central Bank of Jordan. (2015). Jordan Financial Stability Report. Retrieved from http://www.cbj.gov.jo/EchoBusV3.0/SystemAssets/PDFs/EN/FINANCIAL\%20STAB ILITY\%20REPORT\%202015.pdf.

Central Bank of Jordan.(2017). Jordan Financial Stability Report-2017. Retrieved from http://www.cbj.gov.jo/Pages/viewpage.aspx?pageID=45.

Davis, F. (1989). Perceived usefulness, perceived ease of use and user acceptance of information technolog. MIS Quarterly, 13(3), 319-340.

De-Sena Abrahão, R., Moriguchi, S. N., \& Andrade, D. F. (2016). Intention of adoption of mobile payment: An analysis in the light of the Unified Theory of Acceptance and Use of Technology (UTAUT). RAI Revista de Administração e Inovação, 13(3), 221-230.

El-Masri, M., \& Tarhini, A. (2017). Factors affecting the adoption of e-learning systems in Qatar and USA: Extending the Unified Theory of Acceptance and Use of Technology 2 (UTAUT2). Educational Technology Research and Development, 65(3), 743-763.

Gharaibeh, M. K., \& Arshad, M. R. M. (2018). Determinants of Intention to Use Mobile Banking in the North of Jordan: Extending UTAUT2 with Mass Media and Trust. Journal of Engineering and Applied Sciences, 13(8), 2023-2033.

Ghazal, M. (2015, Apr 22). Potential for mobile payments in Jordan promising-experts. published by Jordan Times. Retrieved from http://www.jordantimes.com/news/local/potential-mobile-payments-jordanpromising-\%E2\%80\%94-experts. Accessed September 5, 2018.

Ghazal, M. (2017a, May 21). 'Jordan Internet for All' project launched. published by Jordan Times. Retrieved from http://www.jordantimes.com/news/wef-2017/jordan-internetall\%E2\%80\%99-project-launched. Accessed August 29, 2018.

Ghazal, M. (2017b, Jun 13). Mobile payment transactions reach 13,498 since start of year. published by Jordan Times. Retrieved from 
http://www.jordantimes.com/news/local/mobile-payment-transactions-reach-13498start-year. Accessed August 21, 2018.

International Telecommunication Union (2017). Information and Communication Technology (ICT) Facts and Figures 2017. Available from: https://www.itu.int/en/ITUD/Statistics/Documents/facts/ICTFactsFigures2017.pdf. Accessed 22 November 2019.

Jaradat, M. I. R. M., \& Al-Mashaqba, A. M. (2014). Understanding the adoption and usage of mobile payment services by using TAM3. International Journal of Business Information Systems, 16(3), 271-296.

Jaradat, M. I. R. M., \& Faqih, K. M. (2014). Investigating the moderating effects of gender and self-efficacy in the context of mobile payment adoption: A developing country perspective. International Journal of Business and Management, 9(11), 147-169.

Marketingtochina.com (Jan 29, 2015). Chinese mobile banking payment is booming. Retrieved from http://marketingtochina.com/chinese-mobile-banking-payment-booming.

Ministry of Information and Communications Technology. (2017a). Government of Jordan announce plans for internet for all. Retrieved from http://moict.gov.jo/content/government-of-jordan-announce-plans-for-internet-for-all278.

Ministry of Information and Communications Technology. (2017b). The Minister office: The Minister Speech. Retrieved from http://moict.gov.jo/content/minister-speech.

Moody, J. (2001). Peer influence groups: identifying dense clusters in large networks. Social Networks, 23(4), 261-283.

Morosan, C., \& DeFranco, A. (2016). It's about time: Revisiting UTAUT2 to examine consumers' intentions to use NFC mobile payments in hotels. International Journal of Hospitality Management, 53, 17-29.

Qasim, H., \& Abu-Shanab, E. (2016). Drivers of mobile payment acceptance: The impact of network externalities. Information Systems Frontiers, 18(5), 1021-1034.

Qatawneh, A. M., Aldhmour, F. M., \& Alfugara, S. M. (2015). The Adoption of Electronic Payment System (EPS) in Jordan: Case Study of Orange Telecommunication Company. Journal of Business and Management, 6(22), 139-148.

Raman, A., \& Don, Y. (2013). Preservice teachers' acceptance of learning management software: An application of the UTAUT2 model. International Education Studies, 6(7), 157-164.

Sehwail L, \& Bahou M. (2017, April 24). Interview with The Jordanian Official Television program money and business - financial inclusion [Video file]. Retrieved from https://www.youtube.com/watch?v=5ouJVc7nBqU.

Slade, E. L., Dwivedi, Y. K., Piercy, N. C., \& Williams, M. D. (2015). Modeling consumers' adoption intentions of remote mobile payments in the United Kingdom: extending UTAUT with innovativeness, risk, and trust. Psychology \& Marketing, 32(8), 860-873.

Statista (2017). 5 Billion People to Use Mobile Phones by 2017. Available from: https://www.statista.com/chart/1517/worldwide-mobile-phone-users/. Accessed 23 November 2019.

Statista (2019). Number of mobile phone users worldwide from 2015 to 2020 (in billions). Available from: https://www.statista.com/statistics/274774/forecast-of-mobile-phoneusers-worldwide/. Accessed 23 November 2019.

Telecommunications Regulatory Commission - Jordan. (2016). Number of active mobile subscribers. Retrieved from http://www.trc.gov.jo/Pages/viewpage.aspx?pageID=186.

Vallespín, M., Molinillo, S., \& Ramos, C. M. (2018). Who relies on mobile payment systems when they are on vacation? A segmentation analysis. Turizam: medunarodni znanstveno-stručni časopis, 66(1), 6-18. 
Venkatesh, V., Morris, M. G., Davis, G. B., \& Davis, F. D. (2003). User acceptance of information technology: toward a unified view. MIS Quarterly, 27(3), 425-478.

Venkatesh, V., Thong, J. Y., \& Xu, X. (2012). Consumer acceptance and use of information technology: extending the unified theory of acceptance and use of technology. MIS Quarterly, 36(1), 157-178.
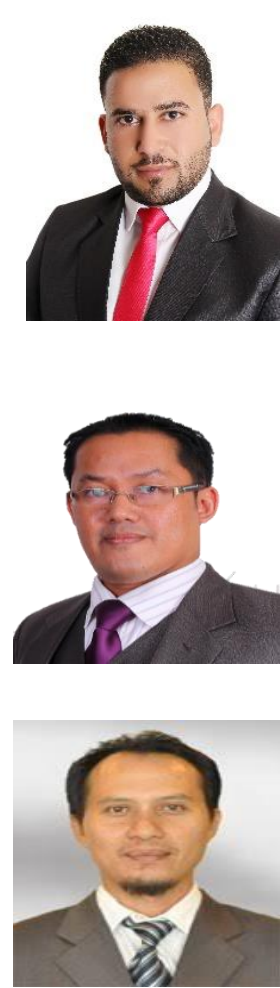

\section{Author's Biography}

Dr. Manaf Al-Okaily is an Assistant Professor at Faculty of Economics and Business, Jadara University. Dr. Al-Okaily obtained his BSc and MSc in Accounting with honor from Jadara University, Irbid, Jordan. He also obtained his $\mathrm{PhD}$ in Accounting Information Systems from University Malaysia Terengganu, Kuala Terengganu, Malaysia. His current research interest is in the area of Accounting and Business Intelligence, Accounting Information Systems, Information Systems Acceptance and Adoption Theories, Technology Acceptance and Adoption, Electronic Auditing, Electronic and Mobile Payment Systems. In addition, His research interest is also concerned with the Quantitative Research Methods as well as Structural Equation Modeling.

Dr. Mohd Shaari Abd Rahman is a Senior Lecturer at the Faculty of Business, Economics and Social Development, and Director of Career and Entrepreneurship Centre at Universiti Malaysia Terengganu, Malaysia. Dr. Mohd Shaari received a bachelor's degree in Accounting (Hons) from Universiti Utara Malaysia, Malaysia. MSc (Accounting \& Finance), from Birmingham in the United Kingdom, Ph.D., from University of Tasmania, Australia. His research interests are accounting information systems, accounting education (E-Learning), technology in accounting. He has published his research works in a number of journals.

Dr. Azwadi Ali is an Associate Professor and Head of Accounting Department in the Faculty of Business, Economics and Social Development at Universiti Malaysia Terengganu, Malaysia. Dr. Azwadi received a bachelor's degree in Accounting and Finance from Lancaster University, United Kingdom. a master's degree in Accountancy from UiTM, and a PhD from Victoria University, Australia. His research interests are accounting information systems (user perspective) and personal finance. He has published his research works in a number of journals and has been appointed as graduate thesis examiner, both inside and outside UMT. 